\title{
Implementation of a multidisciplinary team approach and fish oil emulsion administration in the management of infants with short bowel syndrome and parenteral nutrition-associated liver disease
}

\author{
Ana MGA Sant'Anna MD MSc ${ }^{1}$, Eyad Altamimi MD², Rose-Frances Clause NP-P2 , Joanne Saab RD², \\ Heather Mileski RD², Brian Cameron $M^{3}{ }^{3}$, Peter Fitzgerald $M D^{3}$, Guilherme M Sant'Anna MD PhD
}

\begin{abstract}
AM Sant'Anna, E Altamimi, R-F Clause, et al. Implementation of a multidisciplinary team approach and fish oil emulsion administration in the management of infants with short bowel syndrome and parenteral nutrition-associated liver disease. Can J Gastroenterol 2012;26(5):277-280.
\end{abstract}

OBJECTIVE: To describe the authors' experience with the implementation of a multidisciplinary approach and use of fish oil emulsion (FOE) in the management of infants with short bowel syndrome (SBS) and parenteral nutrition-associated liver disease (PNALD).

METHODS: Between August 2006 and June 2009, four cases of SBS and severe PNALD were managed by the team using specifically developed protocols. The FOE was initiated if serum direct bilirubin levels were $\geq 100 \mu \mathrm{mol} / \mathrm{L}$. To quantify the degree of exposure to high serum direct bilirubin levels over time, the area under the curve (AUC) for each patient was calculated before and after initiation of FOE. Linear regression analyses were performed to evaluate correlations between the AUC, duration of cholestasis and initiation of FOE.

RESULTS: All patients survived and no complications were observed during the study period. After the first patient, FOE was initiated progressively earlier, but poor correlation between the AUC before and after its introduction was observed $\left(\mathrm{r}^{2}=0.41924\right)$. However, there was strong correlation between the duration of PNALD before FOE initiation and time to resolution $\left(r^{2}=0.72133\right)$ : the earlier the FOE was initiated, the shorter the time to resolution.

CONCLUSION: The authors report a positive experience with the implementation of a multidisciplinary approach and the use of FOE in infants with SBS and severe PNALD. The earlier the FOE was initiated during the cholestatic process, the shorter the time to resolution. The present study is a hypothesis generator, raising the question of whether an earlier introduction of this particular therapy can effectively shorten the cholestasis process in these patients.

Key Words: Cholestasis; Fish oil emulsion; Intestinal failure; Multidisciplinary team; Parenteral nutrition-associated liver disease; Short bowel syndrome
L'adoption d'une démarche multidisciplinaire et de l'administration d'une émulsion d'huile de poisson pour la prise en charge des nourrissons ayant un syndrome de l'intestin court et une maladie hépatique associée à la nutrition parentérale

OBJECTIF : Décrire l'expérience des auteurs dans la mise en œuvre d'une démarche multidisciplinaire et de l'utilisation d'une émulsion d'huile de poisson (ÉHP) pour la prise en charge des nourrissons ayant le syndrome de l'intestin court (SIC) et une maladie hépatique associée à la nutrition parentérale (MHANP).

MÉTHODOLOGIE : Entre août 2006 et juin 2009, l'équipe a pris en charge quatre cas de SIC et de grave MHANP au moyen de protocoles adaptés. L'ÉHP était administrée si les taux de bilirubine sérique directs étaient égaux ou supérieurs à $100 \mu \mathrm{mol} / \mathrm{L}$. Pour quantifier le degré d'exposition à de forts taux de bilirubine sérique directe au fil du temps, les chercheurs ont calculé la surface sous la courbe (SSC) de chaque patient avant et après le début de l'ÉHP. Ils ont effectué des analyses de régression linéaire pour évaluer les corrélations entre la SSC, la durée de la cholestase et le début de l'ÉHP.

RÉSULTATS : Tous les patients ont survécu et les chercheurs n'ont observé aucune complication pendant la période de l'étude. Après le premier patient, l'ÉHP a été amorcée progressivement plus tôt, mais la corrélation était faible entre la SSC avant et après le début de son administration $\left(r^{2}=0,41924\right)$. Cependant, les chercheurs ont remarqué une forte corrélation entre la durée de la MHANP avant le début de l'ÉHP et le délai jusqu'à la résolution $\left(\mathrm{r}^{2}=0,72133\right)$ : plus l'ÉHP était amorcée rapidement, plus le délai avant la résolution était court.

CONCLUSION : D'après les auteurs, l'adoption d'une démarche multidisciplinaire et l'utilisation d'ÉHP chez les enfants ayant un SIC et une grave MHANP est une expérience positive. Plus l'ÉHP était entreprise rapidement pendant le processus cholostatique, plus le délai avant la résolution était court. La présente étude est un générateur d'hypothèses, qui incite à se demander si l'adoption de cette thérapie plus rapidement peut raccourcir le processus cholostatique de manière efficace chez ces patients.

A multidisciplinary approach, with coordination of surgical, medical and nutritional management, has been associated with significant improvement in communication and integration of specialized services, increased bowel preservation and decreased episodes of sepsis. This approach, combined with recent advances in surgical techniques and clinical management, has led to an increased survival rate in these infants. Although the administration of parenteral nutrition $(\mathrm{PN})$ is

Short bowel syndrome (SBS) is a malabsorptive state characterized $\checkmark$ by the inability to maintain protein energy, fluid, electrolyte or micronutrient balance when on a conventional diet following bowel resection $(1,2)$. The reported incidence is 22.1 per 1000 neonatal intensive care admissions and 24.5 per 100,0000 live births, with a significantly greater incidence in premature infants who undergo massive resection of the small intestine $(3,4)$.

\footnotetext{
${ }^{1}$ Division of Pediatric Gastroenterology, Montreal Children's Hospital, McGill University, Montreal, Quebec; ${ }^{2}$ Division of Pediatric Gastroenterology;

${ }^{3}$ Division of Pediatric General Surgery, McMaster Children's Hospital, McMaster University, Hamilton, Ontario; ${ }^{4}$ Division of Neonatology, Montreal

Children's Hospital, McGill University, Montreal, Quebec

Correspondence: Dr Ana MGA Sant'Anna, Division of Pediatric Gastroenterology, Montreal Children's Hospital, McGill University, Room 562,

2300 Tupper Street, Montreal, Quebec H3H 1P3. Telephone 514-412-4474, fax 514-412-4392, e-mail ana.santanna@mcgill.ca

Received for publication October 8, 2010. Accepted August 5, 2011
} 
TABLE 1

Patient demographics

\begin{tabular}{|c|c|c|c|c|c|c|c|c|}
\hline \multirow[b]{2}{*}{ Patient } & \multirow[b]{2}{*}{ Diagnosis } & \multirow[b]{2}{*}{ Sex } & \multirow{2}{*}{$\begin{array}{l}\text { Gestational } \\
\text { age, weeks }\end{array}$} & \multirow{2}{*}{$\begin{array}{c}\text { Bowel } \\
\text { length, } \mathrm{cm}\end{array}$} & \multicolumn{2}{|c|}{ Duration, weeks } & \multirow{2}{*}{$\begin{array}{c}\text { Direct bilirubin*, } \\
\mu \mathrm{mol} / \mathrm{L}\end{array}$} & \multirow{2}{*}{$\begin{array}{c}\text { Resolution of } \\
\text { cholestasis }^{\dagger}, \text { weeks }\end{array}$} \\
\hline & & & & & PN & Cholestasis & & \\
\hline 1 & $\begin{array}{l}\text { Gastroschisis, multiple small bowel } \\
\text { atresias and volvulus }\end{array}$ & Male & 34 & $25 / 74^{\ddagger}$ & 20 & 17 & 124 & 32 \\
\hline 3 & $\begin{array}{l}\text { Gastroschisis with proximal jejunum } \\
\text { atresia }\end{array}$ & Female & 33 & $71 / 91^{\ddagger}$ & 12 & 9 & 152 & 10 \\
\hline
\end{tabular}

${ }^{*}$ Direct bilirubin level before Omegaven (Fresenius Kabi A, Germany) was initiated; ${ }^{\dagger}$ Number of weeks after the fish oil emulsion was initiated; ${ }^{\ddagger}$ Bowel length after first surgery and after final serial transverse enteroplasty procedure. PN Parenteral nutrition

paramount in the management of these patients, it has been implicated in the development of liver disease in approximately $30 \%$ to $60 \%$ of infants (5-7). Because some of these patients may progress to liver failure, other strategies such as cycling of PN, supplementation of $\mathrm{PN}$ with taurine, addition of growth factors and reduction of lipid infusion have been proposed with variable results. Evidence suggests that PN-associated liver disease (PNALD) may, in part, be due to the soy oil present in the composition of the fat emulsions, which contains phytosterols that can be harmful by displacing cholesterol from the lipid pool or by increasing the oxidant load on the liver when $>1 \mathrm{~g} / \mathrm{kg}$ is provided $(8,9)$. A special fish oil-based lipid emulsion (Omegaven, Fresenius Kabi A, Germany) has been the most promising intervention because it is metabolized to anti-inflammatory leukotrienes (1012).

In following some of the evidence-based management principles described above, we assembled a multidisciplinary team, and developed and implemented the use of specific protocols for enteral nutrition and $\mathrm{PN}$, which included the administration of a fish oil-based emulsion for patients with SBS and PNALD. In the present article, we report our local experience with the first four consecutive cases managed using this approach.

\section{SBS team and protocols}

\section{METHODS}

Between August 2006 and June 2009, four cases of SBS and severe cholestasis were treated at the McMaster Children's Hospital (Hamilton, Ontario). During the management of the first case, a multidisciplinary team composed of pediatric gastroenterologists, pediatric surgeons, neonatologists, dieticians, nurse practitioners, nurses and a pharmacist was assembled and became responsible for the management of all patients with SBS. The group developed protocols for PN and enteral nutrition, management of PNALD, bacterial overgrowth and recurrent episodes of sepsis. Individual approval for the use of Omegaven was obtained under the Special Access Program of the Health Products and Food Branch of Health Canada. The funding for the medication was obtained by the inpatient pharmacy.

$\mathrm{PN}$ and enteral feeding protocols

In the PN solution, lipids were started at $0.5 \mathrm{~g} / \mathrm{kg}$ to $1 \mathrm{~g} / \mathrm{kg}$, and increased daily up to $3 \mathrm{~g} / \mathrm{kg}$ (20\% Intralipid, Fresenius Kabi, Germany), protein was started at $1.5 \mathrm{~g} / \mathrm{kg}$ to $2 \mathrm{~g} / \mathrm{kg}$, up to $3.5 \mathrm{~g} / \mathrm{kg}$ (aminoplasmin $10 \%$ ), and the initial glucose infusion rate was between $4 \mathrm{mg} / \mathrm{kg} / \mathrm{min}$ and $6 \mathrm{mg} / \mathrm{kg} / \mathrm{min}$. Multivitamins, trace elements and $\mathrm{H}_{2}$ blockers were also added to the solution. The targeted values of $\mathrm{PN}$ were reached gradually and modified according to biochemical results.

Enteral feedings were started slowly, continuously and through a nasogastric tube that was later changed to a gastrostomy tube (13). Expressed breast milk was the first option and encouraged whenever available (13). When expressed breast milk was unavailable, hydrolyzed formulas were used. Amino acid-based formulas were used only when the two first options failed (for example, due to allergy or feeding
intolerance).When patients were clinically stable, oral feeds, in very small volumes, were initiated to stimulate and develop oral motor skills.

\section{PNALD}

Neonatal cholestasis was defined as a serum direct bilirubin (DB) level $>34 \mu \mathrm{mol} / \mathrm{L}(2.0 \mathrm{mg} / \mathrm{dL})$ and severe PNALD as a serum DB level $\geq 50 \mu \mathrm{mol} / \mathrm{L}(2.9 \mathrm{mg} / \mathrm{dL})$. Once the fish oil emulsion was indicated (serum DB level $\geq 100 \mu \mathrm{mol} / \mathrm{L}$ ) the Intralipid solution was decreased to $1 \mathrm{~g} / \mathrm{kg} /$ day and the fish oil emulsion was initiated at a dose of $0.5 \mathrm{~g} / \mathrm{kg} /$ day. If well tolerated, this dose was increased to $1 \mathrm{~g} / \mathrm{kg} / \mathrm{day}$ and the Intralipid maintained at $1 \mathrm{~g} / \mathrm{kg} /$ day. Laboratory blood work was performed once per week and included complete blood count, electrolytes, total bilirubin and DB, liver enzymes, triglycerides and coagulation parameters. Resolution of the cholestasis was defined as a serum DB level of $<34 \mu \mathrm{mol} / \mathrm{L}$.

\section{Management of bacterial overgrowth and sepsis}

Bacterial overgrowth can occur as a result of dysmotility and dilated areas of the bowel $(14,15)$. Therefore, the multidisciplinary team has decided to initiate weekly alternated cycles of empirical prophylactic oral antibiotics in all infants who developed sepsis with a microorganism originally from the small bowel. If another septic episode occurred during the week the patient was off antibiotics, the cycling was stopped and oral antibiotics were given daily.

\section{Data collection and analysis}

Data were collected from the patient's medical records. Serum DB values were 'binned' in one-week periods and presented graphically as the averages of each bin. To quantify the degree of exposure to high levels of serum DB over time, the area under the curve (AUC) for each patient was calculated using the trapezoid rule starting from the first measurement of serum $\mathrm{DB}>34 \mu \mathrm{mol} / \mathrm{L}$ to the time the fish oil emulsion was started (ie, AUC BEFORE), and from the time the emulsion was started to the time the serum DB $\leq 34 \mu \mathrm{mol} / \mathrm{L}$ (ie, AUC AFTER). A linear regression analysis was performed to analyze a possible correlation between AUC BEFORE and AUC AFTER, as well as the duration of PNALD before and after initiation of the fish oil emulsion.

\section{RESULTS}

Demographic data of the four cases are presented in Table 1. Two patients with gastroschisis also had bowel atresias: patient 1 had a jejunal and colonic atresia; and patient 3 had a jejunal atresia.

Time of initiation of the fish oil emulsion and DB level The median serum level of DB when the fish oil emulsion was started was $129 \mu \mathrm{mol} / \mathrm{L}$ (range $73 \mu \mathrm{mol} / \mathrm{L}$ to $169 \mu \mathrm{mol} / \mathrm{L}$ ). After emulsion administration, PNALD resolved in all infants over time. In the first patient, the fish oil emulsion was started after 17 weeks of cholestasis and at a serum DB level of $125 \mu \mathrm{mol} / \mathrm{L}$, while for the following three patients, the administration was initiated progressively earlier: 13 weeks of cholestasis and a serum DB level of $151 \mu \mathrm{mol} / \mathrm{L}$; nine 


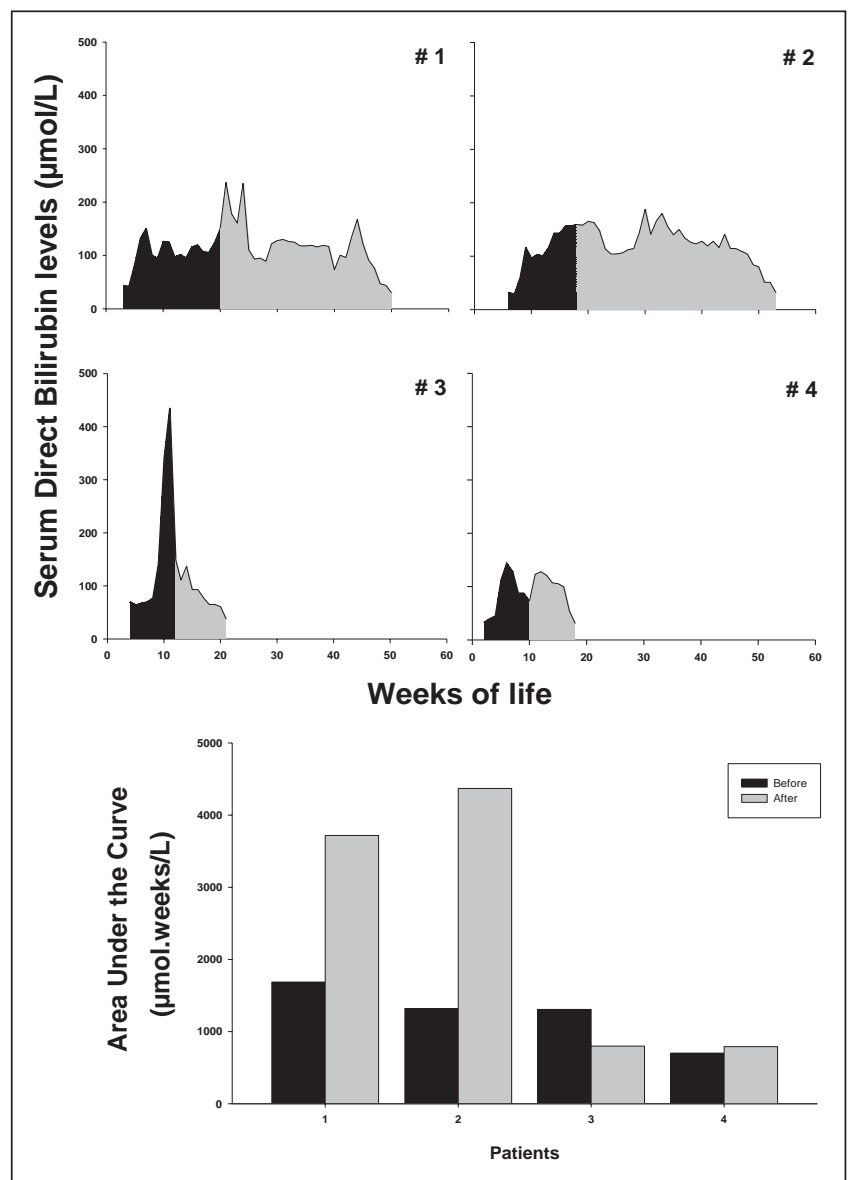

Figure 1) Serum direct bilirubin levels over time. Area under the curve before (dark) and after (grey) the initiation of the fish oil emulsion was calculated and plotted in the bar chart

weeks of cholestasis and a serum DB level of $152 \mu \mathrm{mol} / \mathrm{L}$; and nine weeks of cholestasis and a serum DB level of $73 \mu \mathrm{mol} / \mathrm{L}$ (Table 1 and Figure 1).

Duration of PNALD before initiation of the fish oil emulsion and response to treatment

There was a poor correlation between the AUC BEFORE initiation of the fish oil emulsion treatment and the AUC AFTER (Figure 2A $\left.\left[\mathrm{r}^{2}=0.4192418688\right]\right)$. However, the earlier the fish oil was initiated during the cholestatic process, the shorter the time to resolution (Figure 2B $\left.\left[\mathrm{r}^{2}=0.721336569\right]\right)$. These differences were more evident when comparing patients 2 and 3 , in whom the emulsion was initiated at similar serum DB levels $(151 \mu \mathrm{mol} / \mathrm{L}$ and $152 \mu \mathrm{mol} / \mathrm{L}$, respectively) and AUC (1318.92 and 1307.05, respectively), but resolution of cholestasis occurred much faster in patient 3 , who had four weeks less of cholestasis (nine weeks versus 13 weeks; Figure 1). The durations of PNALD after initiation of the fish oil emulsion in patients 1 to 4 were as follows: 32 weeks, 36 weeks, 10 weeks and nine weeks, respectively (Table 1 ).

\section{Liver function and PN}

Patients 1 and 2 maintained abnormal levels of serum transaminases, while in the other two patients, transaminase levels normalized at approximately the same time the cholestasis resolved. Patient 1 received the fish oil emulsion alone as a lipid source. The three other patients received the fish oil emulsion and Intralipid initially. Intralipid was discontinued in patient 2 after four months of persistent cholestasis despite the use of the fish oil emulsion (cholestasis resolved only after one year of therapy). Patients 3 and 4 received both lipid emulsions. Patient 4 was

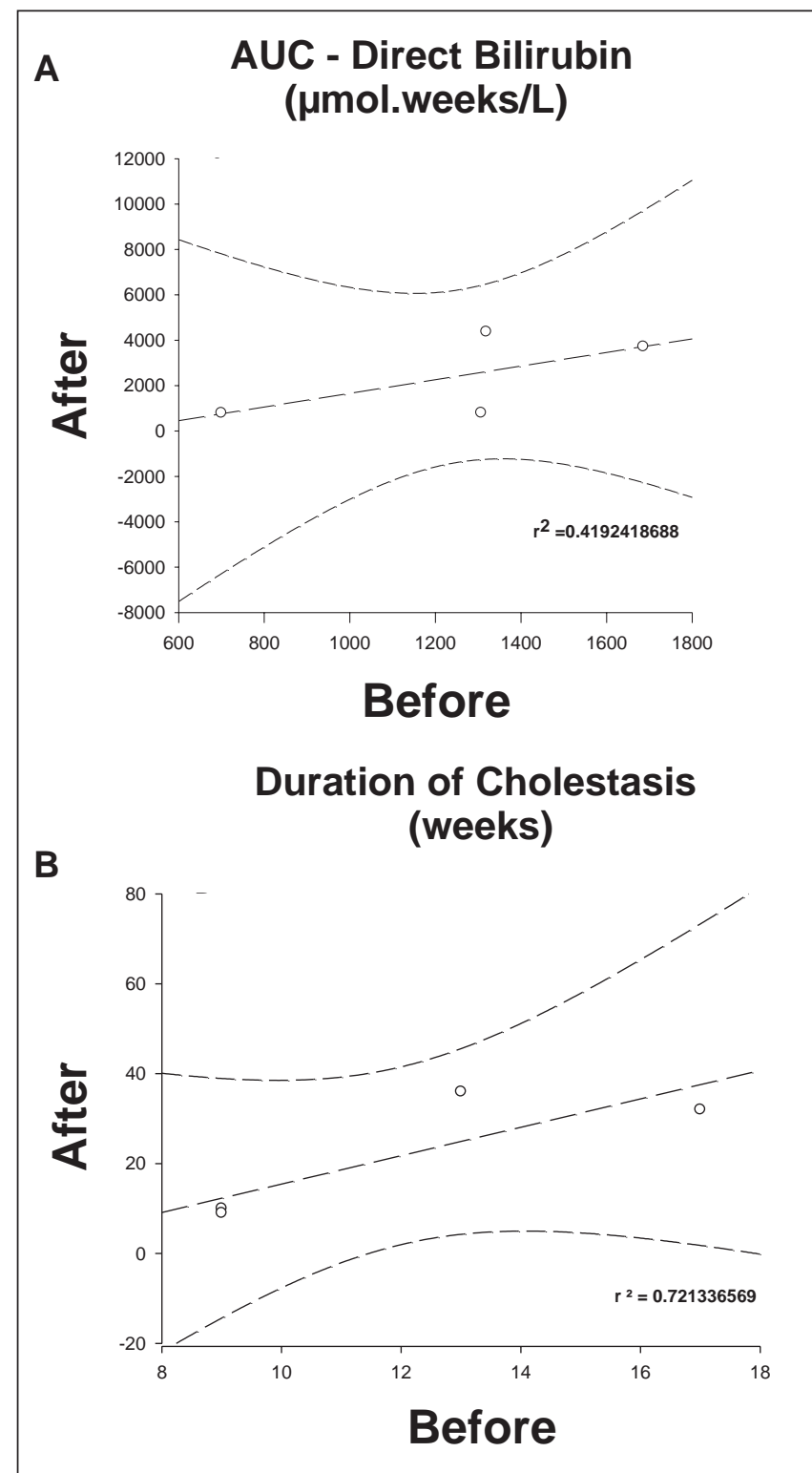

Figure 2) Linear regression analysis of the area under the curve (AUC) for serum direct bilirubin levels (A) and duration (weeks) of severe parenteral nutrition-associated liver disease before and after the initiation of the fish oil emulsion (B)

discharged home on Intralipid only (after receiving the fish oil emulsion for two months), with no return of cholestasis. There were no complications secondary to the use of the fish oil emulsion. The median length of follow up was 104 weeks after resolution of cholestasis (range 100 to 108 weeks) and all patients remain clinically well. Only patient 1 was still on PN (80\% calories) and receiving the fish oil emulsion at this time. None have clinical evidence of PNALD.

Enteral nutrition: All patients were managed according to the enteral nutrition protocol. Enteral tolerance when cholestasis resolved is shown in Table 1. Amino acid-based formulas were used in patients 2, 3 and 4 due to food allergy and/or feeding intolerance. Only one infant (patient 3) developed a severe feeding aversion. At follow-up, all patients were well nourished and had achieved their milestones.

Infection: The major morbidity associated with SBS and severe PNALD was catheter-related blood stream infection (CRBSI), with an average of nine episodes (range five to 15) per patient. All fungal sepsis episodes were treated with intravenous fluconazole and immediate removal of the central line, while Gram-negative sepsis was treated with one full course 
of antibiotics, before considering line removal. Patient 1 required an ethanol lock (70\%) (7) at 2.5 years age, after multiple episodes of CRBSI and extremely difficult central venous access, with successful response.

Surgical management: Patient 1 underwent three serial transverse enteroplasty procedures, and patient 3 underwent one serial transverse enteroplasty procedure.

\section{DISCUSSION}

In the present study, we report our small but positive experience with the implementation of a multidisciplinary approach and the use of specific protocols that included a fish oil emulsion in the PN of infants with SBS and severe PNALD. The positive effects of a multidisciplinary team approach have been previously reported by different groups (16-19). Similar to our four cases, a shift toward an earlier introduction of the fish oil emulsion was also reported in a study in which the first seven infants were started on fish oil emulsion after 34.9 weeks of PN compared with 24.8 weeks for the final five cases: a decrease of almost 10 weeks (11). Our first patient was started on fish oil emulsion only after 17 weeks of PNALD, whereas the final two patients were initiated after nine weeks. We speculate that a combination of a successful experience with the first cases increased awareness about the efficacy and availability of the product, and the absence of side effects have contributed to the earlier initiation of this therapy.

The use of the fish oil emulsion in PN is a relatively new therapy without well-defined criteria for initiation. Therefore, we opted to use a higher threshold (serum DB level $>100 \mu \mathrm{mol} / \mathrm{L}$ ) and our first three patients were started when serum DB levels were $>100 \mu \mathrm{mol} / \mathrm{L}$. Other studies have used similar thresholds (ie, serum DB levels $>91.8 \mu \mathrm{mol} / \mathrm{L}$ [8] or $>137 \mu \mathrm{mol} / \mathrm{L}$ [11]). In our four cases, there was no correlation between the absolute levels of serum DB or the degree of exposure to these high serum DB levels before the fish oil emulsion was initiated (ie, AUC BEFORE) and resolution of PNALD. We are not aware of any study that has evaluated this possible correlation. However, we found a good correlation between the duration of severe PNALD (weeks) before initiation of the fish oil emulsion and time to resolution of cholestasis, which was defined as a serum DB level $<34 \mu \mathrm{mol} / \mathrm{L}$

\section{REFERENCES}

1. O'Keefe SJ, Buchman AL, Fishbein TM, Jeejeebhoy KN, Jeppesen PB, Shaffer J. Short bowel syndrome and intestinal failure: Consensus definitions and overview. Clin Gastroenterol Hepatol 2006;4:6-10.

2. Wales PW, Christison-Lagay ER. Short bowel syndrome: Epidemiology and etiology. Semin Pediatr Surg 2010;19:3-9.

3. Wales PW, de Silva N, Kim J, Lecce L, To T, Moore A. Neonatal short bowel syndrome: Population-based estimates of incidence and mortality rates. J Pediatr Surg 2004;39:690-5.

4. Buchman AL. Etiology and initial management of short bowel syndrome. Gastroenterology 2006;130(2 Suppl 1):S5-S15.

5. Teitelbaum DH, Tracy T. Parenteral nutrition-associated cholestasis. Semin Pediatr Surg 2001;10:72-80.

6. Buchman A. Total parenteral nutrition-associated liver disease. J Parenter Enteral Nutr 2002;26(5 Suppl):S43-8.

7. Le HD, Fallon EM, de Meijer VE, Malkan AD, Puder M, Gura KM. Innovative parenteral and enteral nutrition therapy for intestinal failure. Semin Pediatr Surg 2010;19:27-34.

8. Gura KM, Duggan CP, Collier SB, et al. Reversal of parenteral nutrition-associated liver disease in two infants with short bowel syndrome using parenteral fish oil: Implications for future management. Pediatrics 2006;118:e197-201.

9. Diamond IR, Sterescu A, Pencharz PB, Wales PW. The rationale for the use of parenteral omega-3 lipids in children with short bowel syndrome and liver disease. Pediatr Surg Int 2008;24:773-8.

10. Gura KM, Lee S, Valim C, et al. Safety and efficacy of a fish-oil-based fat emulsion in the treatment of parenteral nutrition-associated liver disease. Pediatrics 2008;121:e678-86.

11. Diamond IR, Sterescu A, Pencharz PB, Kim JH, Wales PW. Changing the paradigm: Omegaven for the treatment of liver failure in pediatric short bowel syndrome. J Pediatr Gastroenterol Nutr 2009;48:209-15.
(8). Other investigators have defined cholestasis resolution only when the serum DB level was zero (11), but did not report the duration of cholestasis before the introduction of the fish oil emulsion.

$\mathrm{PN}$-dependent infants can achieve normalization of marked hyperbilirubinemia with enteral nutrition, but a marked improvement in liver function begins only after full enteral nutrition is tolerated and $\mathrm{PN}$ is discontinued (20). In our four patients, the cholestatic process was resolved independently of the time the enteral feeds were initiated or the intake tolerated (volume or calories). Patient 3 was not receiving any oral intake when the cholestasis resolved. A previous study also reported two patients receiving only $10 \%$ of oral intake and fish oil emulsion when cholestasis resolved (6). All of these observations prompted us to speculate that the duration of the cholestatic process before initiation of the fish oil emulsion may be an important factor in the response to this therapy. Unfortunately, due to the small number of patients, a definitive conclusion cannot be drawn, but our current practice is to start this emulsion sooner in the course of PNALD. The present study can be regarded as a hypothesis generator and future studies evaluating the use of fish oil emulsion should take the duration of the cholestatic process into consideration.

\section{CONCLUSION}

We reported our positive experience with the implementation of a multidisciplinary team approach and use of fish oil emulsion as a lipid source in PN for the management of infants with SBS and severe PNALD. An earlier initiation of the fish oil emulsion during the cholestatic process was associated with a decreased time to resolution. Our study is a hypothesis generator and raises the question of whether an earlier introduction of this particular therapy can effectively shorten the duration of cholestasis.

ACKNOWLEDGEMENTS: Dr Eyad Altamimi was supported by a scholarship from the Jordanian Government. Dr A Sant'Anna and GM Sant'Anna were supported by internal research funds received from the McMaster Children's Hospital.

12. Fallon EM, Le HD, Puder M. Prevention of parenteral nutritionassociated liver disease: Role of omega-3 fish oil. Curr Opin Organ Transplant 2010;15:334-40.

13. Wessel JJ, Kocoshis SA. Nutritional management of infants with short bowel syndrome. Semin Perinatol 2007;31:104-11.

14. O'Keefe SJ. Bacterial overgrowth and liver complications in short bowel intestinal failure patients. Gastroenterology 2006;130(2 Suppl 1):S67-9.

15. Cole CR, Frem JC, Schmotzer B, et al. The rate of bloodstream infection is high in infants with short bowel syndrome: Relationship with small bowel bacterial overgrowth, enteral feeding, and inflammatory and immune responses. J Pediatr 2010;156:941-7.

16. Modi BP, Langer M, Ching YA, et al. Improved survival in a multidisciplinary short bowel syndrome program. J Pediatr Surg 2008;43:20-4.

17. Diamond IR, de Silva N, Pencharz PB, Kim JH, Wales PW. Neonatal short bowel syndrome outcomes after the establishment of the first Canadian multidisciplinary intestinal rehabilitation program: Preliminary experience. J Pediatr Surg 2007;42:806-11.

18. Spencer AU, Kovacevich D, McKinney-Barnett M, et al. Pediatric short-bowel syndrome: The cost of comprehensive care. Am J Clin Nutr 2008;88:1552-9.

19. Torres C, Sudan D, Vanderhoof J, et al. Role of an intestinal rehabilitation program in the treatment of advanced intestinal failure. J Pediatr Gastroenterol Nutr 2007;45:204-12.

20. Javid PJ, Collier S, Richardson D, et al. The role of enteral nutrition in the reversal of parenteral nutrition-associated liver dysfunction in infants. J Pediatr Surg 2005;40:1015-8. 


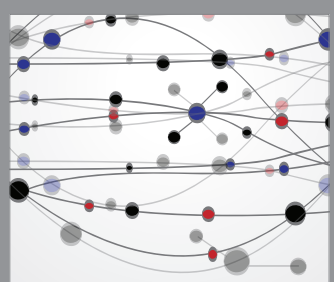

The Scientific World Journal
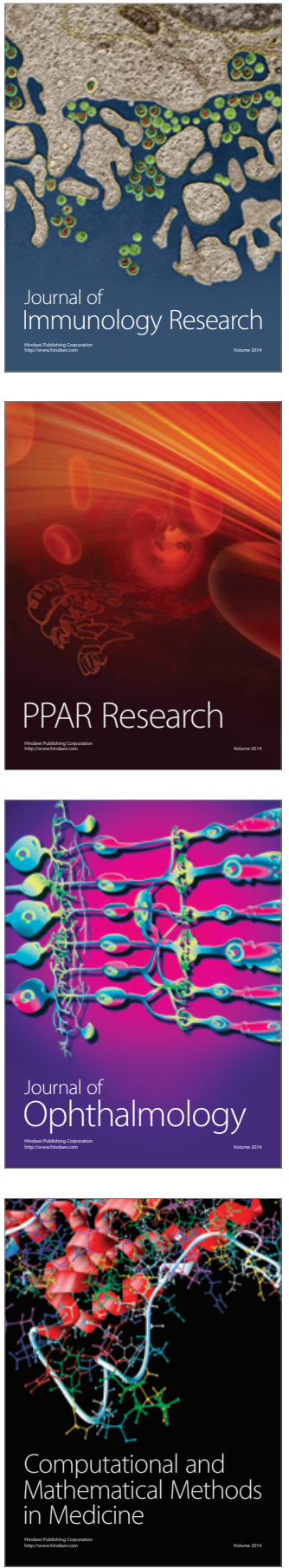

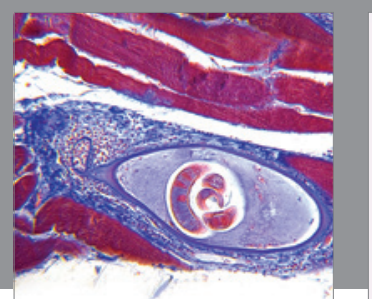

Gastroenterology Research and Practice

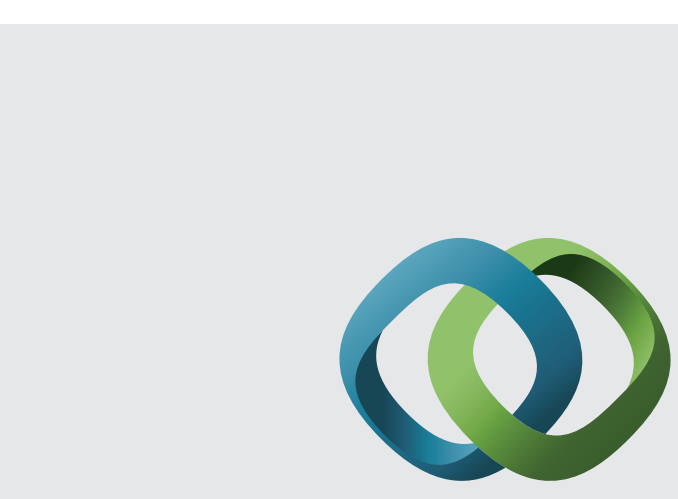

\section{Hindawi}

Submit your manuscripts at

http://www.hindawi.com
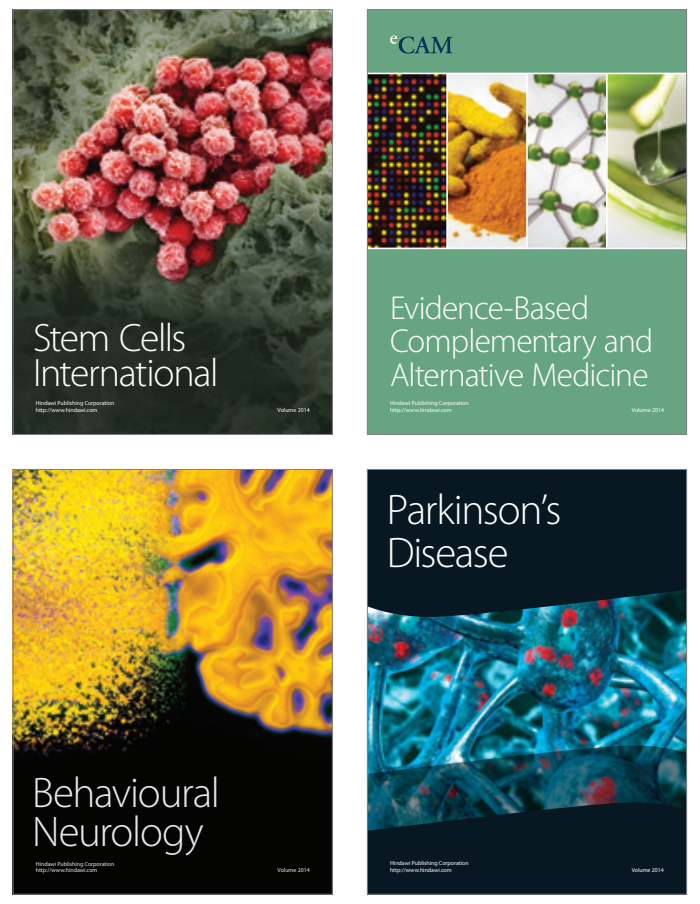
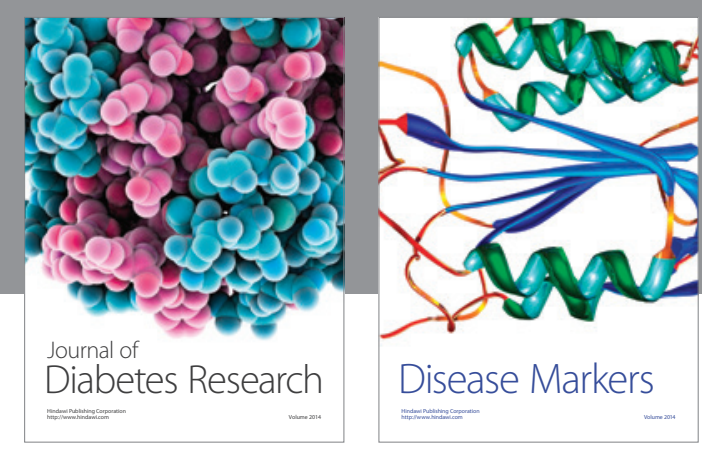

Disease Markers
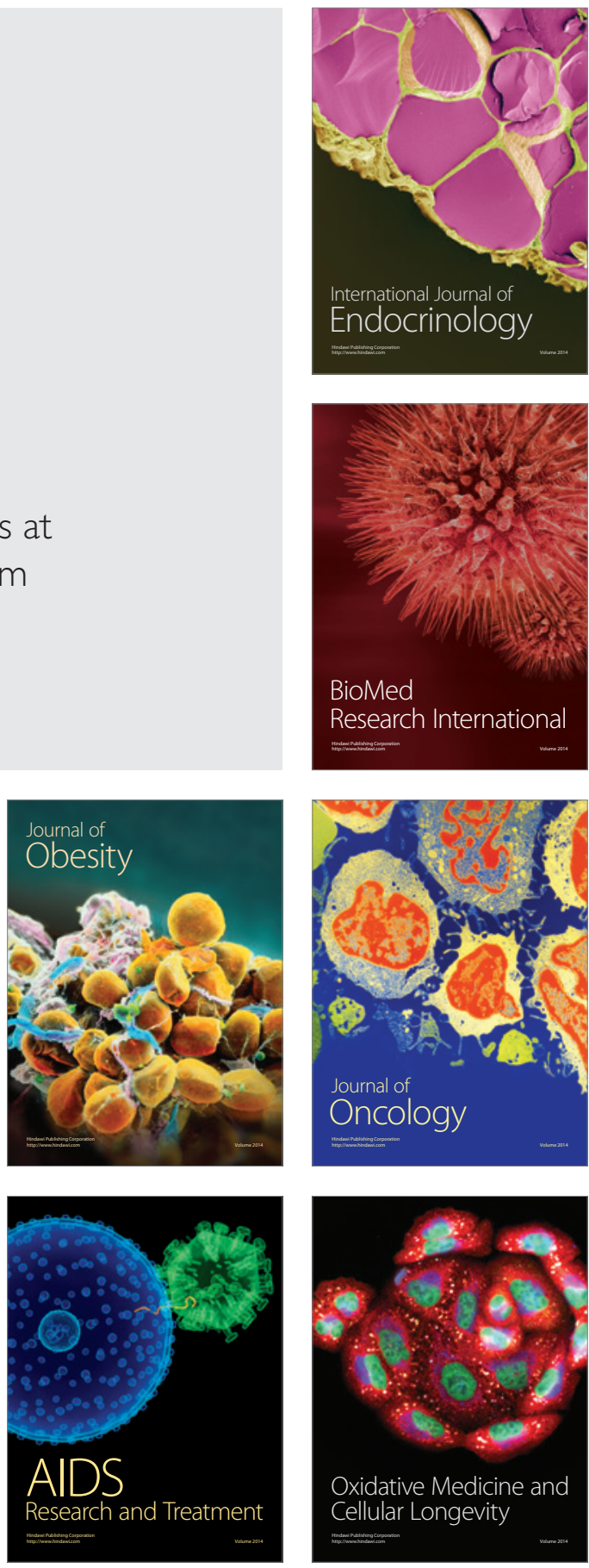